\title{
Sovětský svaz za M. S. Gorbačova
}

\author{
Stanislav Kulhánek \\ Vedoucí práce: doc. PhDr. František Stellner, Ph.D.

\section{Úvod}

Tato práce se zabývá situací v SSSR za M. S. Gorbačova. Analyzované období začíná 11. března 1985, kdy byl Gorbačov zvolen do funkce generálního tajemníka ÚV KSSS. Konec analyzovaného období je spojen s rozpadem SSSR, tzn. s koncem roku 1991.

Práci jsem rozdělil do dvou částí, které se odlišují především svými cíli. První část práce charakterizuje výchozí situaci této supervelmoci z hlediska ideologie, hospodářství a mocenských skupin. Vystihuje změny v těchto charakteristikách po nástupu Gorbačovského vedení k moci. Cílem první části je tedy čtenáře seznámit s obecnými proměnami reálií v daném období.

Ve druhé části práce jsou již uvedeny vybrané př́klady konkrétních kroků, které byly sovětským vedením uskutečněny. U jednotlivých kroků jsou nastíněny jejich výchozí příčiny, zamýšlené důsledky a nezamýšlené dopady. Vzhledem k délce zkoumaného období a množství zajímavých opatření jsem vybral pouze prohibici, prŕčiny inflace v sovětské ekonomice, snahu o rozvoj podnikatelské činnosti a změny v zahraniční politice. Přesto se domnívám, že i na těchto opatřeních lze doložit obtížnost kroků prováděných ve snaze reformovat sovětský systém a především doložit nesnadnou předvídatelnost dopadů těchto kroků.

Čtenáři by se mohlo zdát, že řada významných událostí byla pominuta, avšak tato práce není vedena snahou o vytvoření etapizovaného obrazu sovětských dějin tohoto období, což vzhledem k rozsahu není ani možné. Naopak má na několika málo událostech ukázat k jak neefektivním řešením existujících problémů sovětský systém dospíval.

Množství literatury vztahující se k dané problematice považuji za dostatečné. Jejím určitým nedostatkem však je, že se obvykle věnuje primárně politickým změnám, což mě přivedlo $\mathrm{k}$ rozhodnutí se vnitropolitickými reformami $\mathrm{v}$ této práci hlouběji nezabývat, přestože jejich dopad v žádném př́padě nepodceňuji.

\section{Charakteristika hospodářství}

Americký ekonom P. J. Boettke charakterizuje sovětskou ekonomiku jako tržní hospodářství dominujících monopolních výrobců a subjektů doprovázené obrovskými a svévolnými vládními zásahy. ${ }^{1}$ Bez jakýchkoliv problémů se dá souhlasit s tvrzením, že v sovětské ekonomice byla monopolní struktura. Podniky byly v socialistickém vlastnictví, byly kontrolovány státem, ${ }^{2}$ a proto konkurence mezi těmito podniky se zdála být zbytečná a zdánlivě nežádoucí. Přestože formálně byl vlastníkem všeho lid, de facto byla vlastníkem státního hospodářství nomenklatura. ${ }^{3}$ Představa monopolizace vycházela z ideji, že i v kapitalizmu dojde postupně ke vzniku jen několika málo monopolů, které se nakonec spojí

1 BOETTKE, P. J.: Why Perestroika failed. The Politics and Economics of Socialist Transformation, str. 59.

2 STEPHAN, P. B. III: Perestroyka and Property: The Law of Ownership in the Post-Socialist Soviet Union, str. 37.

3 STEPHAN, P. B. III: Perestroyka and Property: The Law of Ownership in the Post-Socialist Soviet Union, str. 63. 
v jeden celek. ${ }^{4}$ Monopolizaci sovětské ekonomiky dokládá, že řada produktů byla vyráběna jedním či dvěma výrobci a ve strojírenství bylo v roce 198816 absolutních monopolistů a 180 monopolních výrob. První krok učiněný pro potlačení monopolizace v ekonomice byl uskutečněn až v roce $1990 \mathrm{v}$ rámci usnesení rady ministrù. ${ }^{5}$

Svévolné vládní zásahy byly podstatou centrálně plánované ekonomiky. V SSSR existovaly dvě ř́íící linie: státní struktura a hierarchie KSSS. Je jasné, že stranická hierarchie, která prostupovala celou společností byla důležitější. Tyto linie se však lišily v principu hospodářského řízení, zatímco státní řízení bylo založeno na odvětvovém principu, tak stranická hierarchie byla založena na teritoriálním principu. Hovoří-li tedy Boettke o vládních zásazích, jedná se o vládní zásahy v režii KSSS. Ty byly prostřednictvím politbyra prosazovány přes vládu na Gosplan. ${ }^{6}$ To znamená, že toto direktivní plánování ekonomiky nebylo prováděno z hlediska ekonomického, ale politického a ideologického. Výstižně to v roce 1984 vyjádřil tehdejší generální tajemník K. U. Černěnko: „činnost-hospodářská, metody-politické".?

\section{Schéma č. 1: Stranická a státní struktura}

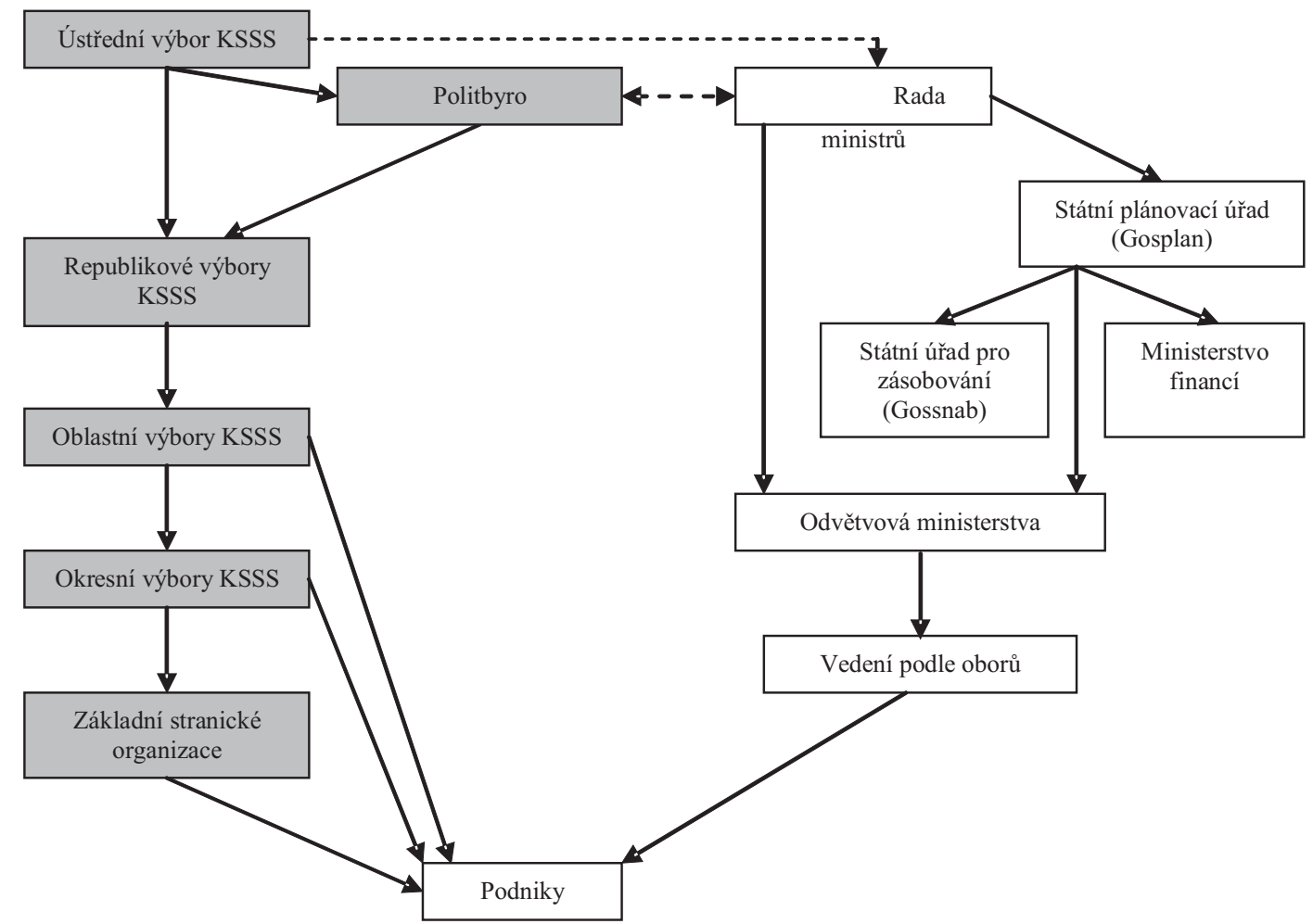

Zdroj: JASIN, E. G.: Rossijskaja ekonomika. Istoki i panorama rynochnykh reform, str. 35, doplněno o vlastní úpravy.

4 Firma při svém růstu snižuje transakční náklady, ale naopak spolu s jejím růstem se zvyšují náklady řízení spojené s koordinací činností ve firmě. Tyto náklady spolu s dalšími faktory mají vliv na to, že se v kapitalizmu nevytvořily pouze monopoly.

5 POPOV, V. - SCHMELEV, N.: Sovetskaja ekonomika: ot plana k rynku, str. 81, 83.

6 Státní plánovací úřad založený v r. 1921.

7 MAU, V. A.: Ekonomika i vlastj. Političheskaja istorija ekonomičeskoj reformy v Rossii, 1985-1994 gg, str. 20. 
Ovšem s třetím faktorem Boettkeho charakteristiky sovětské ekonomiky se dá souhlasit jen stěží. A to, že to byla tržní ekonomika, i když postižená výše uvedenými deformacemi. Přece základním atributem tržního hospodářství je existence trhu. Jaký však byl v SSSR v rámci státem ovládaných podniků trh a prostor pro svobodné jednání podniků? Veškeré chování podniků bylo stanoveno plánem a prostor pro svobodné chování omezen mimo jiné i př́iděly výrobních zdrojů. Tento Boettkeův výrok pochází bezesporu z faktu, že i po dobu fungování centrálně plánované ekonomiky existoval v SSSR institut tržní ceny. Tento institut však existoval mimo oficiální ekonomiku a byl charakteristikou ekonomiky paralelní. Boettke tedy ve své argumentaci obě tyto ekonomiky shrnuje dohromady a hovoř́ o nich jako o vzájemně si nekonkurujících, mezi kterými je vztah symbiózy. ${ }^{8}$ Kvůli výše uvedeným faktům s tímto shrnutím nesouhlasím a považuji za nutné držet se odlišování těchto dvou systémů. Fungování či spíše nefungování oficiálního hospodářství bylo doprovázeno existencí jakési spontánní na centru (tj. straně) nezávislé ekonomiky. Právě proto považuji za nejvhodnější v tomto kontextu používat pojem paralelní ekonomika. Tyto dvě ekonomiky se lišily nejen svými základními charakteristikami, ale nemusely být nutně nekonkurujícími si, jak bude ukázáno dále.

V následující tabulce bych chtěl přehledně demonstrovat rozdíly těchto dvou ekonomik v prostředí SSSR a tím podpořit jejich odlišování.

Tabulka č. 1: Vztah oficiální a paralelní ekonomiky

\begin{tabular}{|l|l|l||}
\hline \multicolumn{1}{|c|}{ Ekonomika } & \multicolumn{1}{|c|}{ Oficiální } & \multicolumn{1}{c|}{ Paralelní } \\
\hline \hline Subjekty & Podniky, jednotlivci, stát & Jednotlivci \\
\hline Objekty & $\begin{array}{l}\text { V plánu zachycené statky } \\
\text { a služby }\end{array}$ & $\begin{array}{l}\text { Statky a služby z oficiální ekonomiky } \\
\text { a zároveň vznikající v paralelní }\end{array}$ \\
\hline Charakter trhu & Plánem určený rozsah i velikost & $\begin{array}{l}\text { Z důvodu bezpečnosti velmi } \\
\text { segmentovaný }\end{array}$ \\
\hline Charakter vztahu & Formalizovaný & Založený na důvěre, známosti \\
\hline Utváření ceny & $\begin{array}{l}\text { Plánem (zpravidla na základě } \\
\text { pracovní teorie hodnoty) }\end{array}$ & Tržním způsobem \\
\hline Zúčtování & $\begin{array}{l}\text { Ve fyzických jednotkách stano- } \\
\text { vených plánem či v penězích (tj. } \\
\text { fakticky poukázkách př́dělového } \\
\text { systému) }\end{array}$ & $\begin{array}{l}\text { V penězích, bartrem či protislužbou } \\
\text { (ty - mně, já - tobě) }\end{array}$ \\
\hline Řešení sporů & $\begin{array}{l}\text { Obrácením se na nadř́zenou } \\
\text { instituci }\end{array}$ & Vzájemným jednáním \\
\hline
\end{tabular}

Zdroj: autor.

Jak již bylo řečeno tyto dva ekonomické systémy se nemusely jen doplňovat, ale jejich vztahy byly mnohem pestřejší. Tímto tématem se zabýval F. J. M. Feldbrugge, který přišel s následujícím výčtem povah těchto vztahů: ${ }^{9}$

1. velká nezávislost (např. u nelegálního prodeje valut, „,veksláci“),

2. vzájemná konkurence (např. poskytování služeb - opravy v domácnosti, „meloucháři“),

3. vyvážená konkurence (v odvětvích, kde stát na svou činnost částečně rezignoval, např. v produkci zemědělských potravin),

8 BOETTKE, P. J.: Why Perestroika failed. The Politics and Economics of Socialist Transformation, str. 66, 67.

9 FELDBRUGGE, F. J. M.: Government and Shadow Economy in the Soviet Union, str. 531. 
4. parazitní symbióza (paralelní ekonomika je kompletně začleněna do oficiální, vysává její zdroje - napřs. podpultový prodej, fungování „privátního“ podnikání pod rouškou státního podniku),

5. kooperativní symbióza (zajiš ování podniku vším potřebným ke splnění plánu, „tolkači“).

Uvedenou charakteristiku vztahů je možné přehledně znázornit na níže uvedené úsečce.

\section{Schéma č. 2: Vztahy oficiální a paralelní ekonomiky}

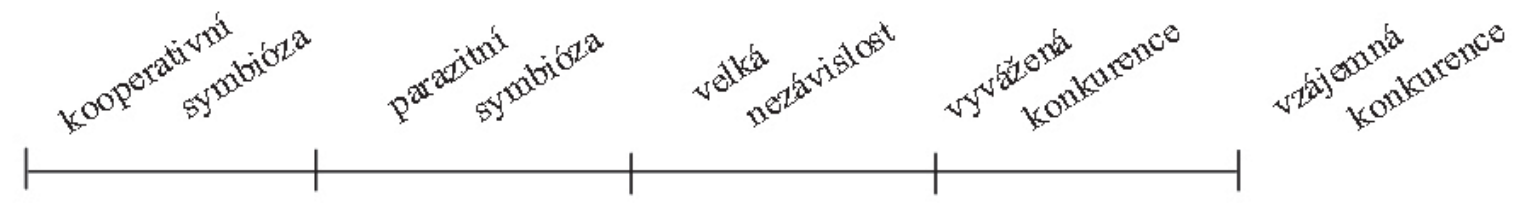

Zdroj: autor.

Vysvětlení vztahu těchto ekonomik se ovšem neobejde bez objasnění příčin vzniku paralelní ekonomiky. Základní příčinou její existence byl neustále prŕítomný deficit statků a služeb. Spotřebitelé nemohli své potřeby odhalit pomocí poptávky, protože ta v oficiální ekonomice neexistovala. Docházelo tak k plýtvání vzácných zdrojů, nebo na jedné straně bylo vyráběno zboží, o které nebyl zájem při současném nedostatku jiného zboží. Tato situace nemohla vést $\mathrm{k}$ ničemu jinému, než ke spekulacím či pokusům o pokoutní výrobu deficitních statků. Spekulace jakožto opětovný prodej nakoupených statků za účelem zisku byla státem postihována jako parazitizmus. ${ }^{10}$ Ve fungujícím tržním hospodářství spekulanti svou snahou o dosažení vlastního zisku urychlují přesun výrobních faktorů z upadajících odvětví k perspektivní výrobě a tím zvyšují efektivnost hospodářství. V centrálně plánovaném hospodářství však vzhledem k neexistenci tržních cen v oficiální ekonomice spekulanti neměli vliv na přesun výrobních faktorů, nebo jejich rozmístění bylo určeno plánem. Existence nedostatků byla ještě prohlubována tzv. efektem honby za deficitem ${ }^{11}$, který se projevoval tím, že když lidé viděli frontu na určité zboží, tak se do té fronty postavili také, nebo předpokládali, že toto zboží nebude nadále k dostání. V důsledku tohoto jednání se zboží skutečně deficitním stalo. Fronta tak byla signálem o vzácnosti statku a nahrazovala cenový systém. To vše vedlo ke vzniku paralelní ekonomiky, která tento deficitní tlak mírnila. Na druhou stranu je zcela patrné, že paralelní ekonomika se dostávala do role jakési opory oficiální ekonomiky. Tento nezamýšlený efekt vedl k mnohem delšímu trvání největšího ekonomického experimentu 20. století, což potvrzují i následující slova ruského ekonoma Jasina: ,jestliže by se v tomto systému dělalo vše podle pravidel, sám by brzy zahynul a žit v něm by bylo jednoduše nemožné.". ${ }^{12}$

Příčinu vzniku paralelní ekonomiky by se dalo odbýt existencí deficitu. To ovšem není celá pravda. Její vznik a rozvoj byl zcela určitě také ovlivněn existencí podnikatelského ducha a snahou o seberealizaci. V tržním hospodářství se může tato vlastnost řady lidí projevit ve svobodném podnikání, to ovšem v SSSR úplně možné nebylo. Proto se prostorem pro uplatnění jejich vlastností a dosažení cílů stala právě paralelní ekonomika.

10 STEPHAN, P. B. III: Perestroyka and Property: The Law of Ownership in the Post-Socialist Soviet Union, str. 36

11 RADCHENKO, V. V.: Ekonomičeskie zakony i perestrojka socialističeskogo chozjastvovanija, mežvuzovskij sbornik statej, str. 27.

12 JASIN, E. G.: Rossijskaja ekonomika. Istoki i panorama rynočnych reform, str. 44. 


\section{KSSS a nomenklatura}

Jak již bylo uvedeno v SSSR existovaly dvě rídící linie: státní struktura a stranická hierarchie. Postavení vlády bylo zcela odlišné od vlád v demokratických státech. Na složení vlády, na její činnost měla absolutní vliv KSSS. Vliv KSSS na vládu v zemi se prosazoval především přes politbyro. Politbyro byl orgán, který přijímal nejzávažnější politická rozhodnutí. Jeho členové zpravidla zastávali i klíčové funkce ve státní struktuře, tzn. docházelo k personálnímu propojení mezi politbyrem a radou ministrů. Rozhodování však vypadalo asi tak, že ministr plnil úkoly a postupoval podle pokynů dohodnutých na jednáních tohoto stranického orgánu.

Dění ve státě však určovala uzavřená mocenská struktura, tj. nomenklatura. Taková struktura vyplývala $\mathrm{z}$ totalitního charakteru SSSR. Právě ona „Z vyšších míst“ rozhodovala o obsazování pozic ve straně, státní správě, diplomacii, podnicích, školství, armádě apod. Nomenklatura maximalizovala vlastní blahobyt, čímž vytvářela negativní externality pro zbytek populace. ${ }^{13}$ To dokládá i to, že docházelo ke kupčení s funkcemi, kdy např. v Ázerbájdžánu bylo možné si koupit funkci okresního velitele policie za 50000 rublů, okresního tajemníka strany za 200000 rublů. ${ }^{14}$

\section{Regionální vládci}

Prováděné reformy, které byly Západem vítány, ještě více zhoršovaly celkový stav hospodářství. Oficiální ekonomika nebyla schopna uspokojovat potřeby občanů a to vedlo ke stále silnější pozici ekonomiky paralelní. Neúnosný deficit vedl k regionalizaci ekonomiky. Vůdci republik se snažili zabezpečit potřeby jen vlastního regionu a tím si udržet a př́ípadně posílit svou pozici. ${ }^{15}$ Vznikaly bariéry na silnicích, které měly zamezit vývozu deficitního zboží z regionů, každá oblast se domnívala, že právě ona je okrádána ostatními. ${ }^{16}$ Docházelo tak k narušování ekonomických svazkủ mezi regiony země, postupně narůstala národnostní a náboženská nesnášenlivost mezi různými skupinami obyvatelstva, to postupně přestalo věřit $\mathrm{v}$ možnost překonání krize a nacházelo se $\mathrm{v}$ bezperspektivnosti. ${ }^{17}$ Rozplynula se iluze o „slévání národností v jediný sovětský národ““. ${ }^{18}$ Tyto fakty přispěly k oslabování moci centra, tj. vlády SSSR, a naopak vedly k výraznému posílení pozic regionálních autorit, které byly vnímány tamními obyvateli jako ty, které hájí jejich zájmy. To se nakonec stalo i jednou z prričin rozpadu SSSR. Separatistické tendence se začaly projevovat napříč SSSR. První vlaštovkou byla deklarace estonského Nejvyššího sovětu o suverénnosti Estonska z 16. listopadu 1988, i když bylo toto rozhodnutí již 18. listopadu jako protiústavní zrušeno Prezidiem Nejvyššího sovětu SSSR. ${ }^{19}$ Narůstající rozpory vyústily v prohlášení $9+1^{20} \mathrm{v}$ dubnu 1991, které seznamovalo veřejnost se zahájením práce na nové svazové smlouvě. V srpnu den před jejím podpisem však došlo k provedení puče, který od-

13 StePHAN, P. B. III: Perestroyka and Property: The Law of Ownership in the Post-Socialist Soviet Union, str. 45-46.

14 DURMAN, K.: Útěk od praporů, Kreml a krize impéria 1964-1991, str. 251.

15 SUSLOV, JU. P.: Radikalnye peremeny v SSSR (1985-1991 gg.), str. 9.

16 JASIN, E. G.: Rossijskaja ekonomika. Istoki i panorama rynočnych reform, str. 119.

17 ZHUKOV, V. I.: Rossijskie preobrazovanija: sociologija, ekonomika, politika, str. 30.

18 DURMAN, K.: Útěk od praporů, Kreml a krize impéria 1964-1991, str. 361.

19 PODBEREZKIN, A. I. i kol.: Rossija - 2000. Sovremennaja političeskaja istorija (198 1999 gg.), T. 1, Chronika i analitika. Naučnoe izdanie, str. 683.

20 (9 = Rusko, Ukrajina, Bělorusko, Uzbekistán, Kazachstán, Ázerbájdžán, Kyrgyzstán, Tádžikistán, Turkmenistán) $+(1=$ SSSR $)$. 
stavil od moci Gorbačova a centrální autority. Moc v Moskvě se přesunula k prezidentovi Ruska Borisu Jelcinovi a Rusko se pod jeho vedením postavilo do čela boje za suverenitu republik. ${ }^{21}$ SSSR se tak v noci z 31. prosince 1991 rozpadl, přestože v březnu téhož roku hlasovalo $76,4 \%{ }^{22}$ občanů v celosovětském referendu pro jeho zachování.

\section{Byrokracie a vojensko-průmyslový komplex}

Postavení byrokracie je vždy spojeno se vztahem ,pána a správce (principal-agent)““. ${ }^{23}$ Byrokracie stejně jako v jiných společenských uspořádáních těžila ze své pozice správce, kterou zastávala ve vztahu k nomenklatuře, občanům a nadřízeným institucím. Je tedy zřejmě, že právě lidé př́slušící k byrokracii neměli zájem o jakékoliv změny a patřili k nejkonzervativnějším silám ve státě. Byrokracie odmítala demokratizaci společenského života, která měla vést k rozvoji samosprávy na všech úrovních. ${ }^{24}$ Od ledna 1987, kdy Gorbačov na plénu ÚV KSSS požadoval vedle probíhající reformy shora také demokratizaci, „,vstoupil stranický aparát do otevřené konfrontace s reformním kurzem “. ${ }^{25}$ Nejradikálněji se tyto protireformní postoje byrokracie projevily během 18. až 22. srpna 1991, kdy se tzv. Státní výbor pro mimořádný stav pokusil o již zmíněný puč. Gorbačov byl internován na chatě v krymském Forosu a byl mu odebrán i jaderný kufř́ik ${ }^{26}$. Zajímavější je však složení výboru: viceprezident, premiér, první zástupce předsedy Rady obrany SSSR, předseda KGB, ministr vnitra SSSR, ministr obrany SSSR, prezident Asociace státních podniků a předseda Zemědělského svazu SSSR. Puč byl tedy revanšem stranicko-státní byrokracie, která v průběhu perestrojky ztrácela moc. ${ }^{27} \mathrm{Za}$ zmínku stojí, že v době provedení puče byla KSSS natolik paralyzována, že po celou dobu politbyro ani sekretariát ÚV KSSS nevydaly žádné prohlášení. $^{28}$

„Vidíme, jak silné postavení má ve vedoucích kapitalistických zemích agresivně a militaristicky smýšlejici i jednající část vládnoucí třídy. Její oporou je mocný vojenskoprìmyslový komplex, jehož zájmy zasahuji svými kořeny do samotné podstaty kapitalistického zrrizení a který z výroby zbraní těži obrovské zisky na účet daňových poplatníkü. " ${ }^{29}$ Tuto větu napsal Gorbačov ve své knize z roku 1987, jsem přesvědčen, že musel vědět, nakolik se hodí i pro charakteristiku vojenskoprůmyslového komplexu ${ }^{30}$ v SSSR. Danou větu stačí jen poněkud modifikovat. Existence vojenskoprůmyslového komplexu byla nutnou podmínkou pro udržení vojenské parity s USA. Zároveň však polykal kolosální peněžní pro-

21 JASIN, E. G.: Rossijskaja ekonomika. Istoki i panorama rynočnych reform, str. 123.

22 PODBEREZKIN, A. I. i kol.: Rossija - 2000. Sovremennaja političeskaja istorija (1985-1999 gg.), T. 1, Chronika $i$ analitika. Naučnoe izdanie, str. 638.

23 Pojem ekonomické teorie školy veřejné volby (public choice) charakterizující monopolní postavení a informační převahu byrokracie, která se snaží o dosažení vlastního prospěchu.

24 GORBAČOV, M. S.: Přestavba a nové myšleni pro naši zemi a pro celý svět, str. 27.

25 DURMAN, K.: Útěk od praporů, Kreml a krize impéria 1964-1991, str. 343-344.

26 Zařízení a kódy pro ovládání jaderných zbraní, které Gorbačov držel jakožto vrchní velitel ozbrojených sil.

27 PODBEREZKIN, A. I. i kol.: Rossija-2000. Sovremennaja političeskaja istorija (1985-1999 gg.), T. 1, Chronika i analitika. Naučnoe izdanie, str. 642.

28 PODBEREZKIN, A. I. i kol.: Rossija-2000. Sovremennaja političeskaja istorija (1985-1999 gg.), T. 1, Chronika $i$ analitika. Naučnoe izdanie, str. 642.

29 GORBAČOV, M. S.: Přestavba a nové myšlení pro naši zemi a pro celý svět, str. 131.

30 Pojem charakterizující propojení zájmů: armády (disponovat špičkovými vojenskými technologiemi a mít silné postavení ve společnosti), podniků (maximalizovat počet vojenských zakázek), vědců (provádět výzkumy). V konečné fázi může vést od zajištění účelné obrany k nadměrnému zbrojení a hledání neexistujícího nepř́itele. 
středky ve výši $40 \%$ rozpočtových výdajü ${ }^{31}$, deficitní zdroje, nejnovější technologie a zařizení, koncentroval ty nejlepší specialisty. Z těchto výhod, které odčerpávaly prostředky pro občanská odvětví, však čerpala opět byrokracie a vojenská elita. Reálný socializmus tak vedl k vykořis ování osob stojících mimo struktury byrokracie a nomenklatury, nebo ony získávaly na účet „běžných občanů“ větší podíl společenského bohatství, než jaký byl jejich vklad ${ }^{32}$.

Avšak i generalita si uvědomovala, že vojenské výdaje jsou př́lliš velkou zátěží pro hospodářství. Náčelník generálního štábu maršál Achromějev si byl vědom, že armáda by měla projít vlastní přestavbou. Armádní velení samozřejmě požadovalo při jakýchkoliv ústupcích při odzbrojování jejich posouzení z hlediska zajištění dostatečné obrany SSSR a jeho impéria. Dne 7. prosince 1988, kdy Gorbačov v OSN ohlásil snížení stavu sovětských ozbrojených sil ve střední Evropě, opustil Achromějev ze ,zdravotních důvodů“ svou funkci. Můžeme říct, že právě od této doby ztrácel Gorbačov podporu armády, nebo nový náčelník generálního štábu Mojsejev i ministr obrany maršál Jazov se domnívali, že armáda a existence vojáků i zajištění jejich rodin bylo obětováno perestrojce. ${ }^{33}$ Armádní velení se tak přiklonilo ke konzervativním odpůrcům probíhajících změn.

\section{Graf č. 1: Vojenské výdaje SSSR, USA a vojenských bloků (v miliardách USD)}

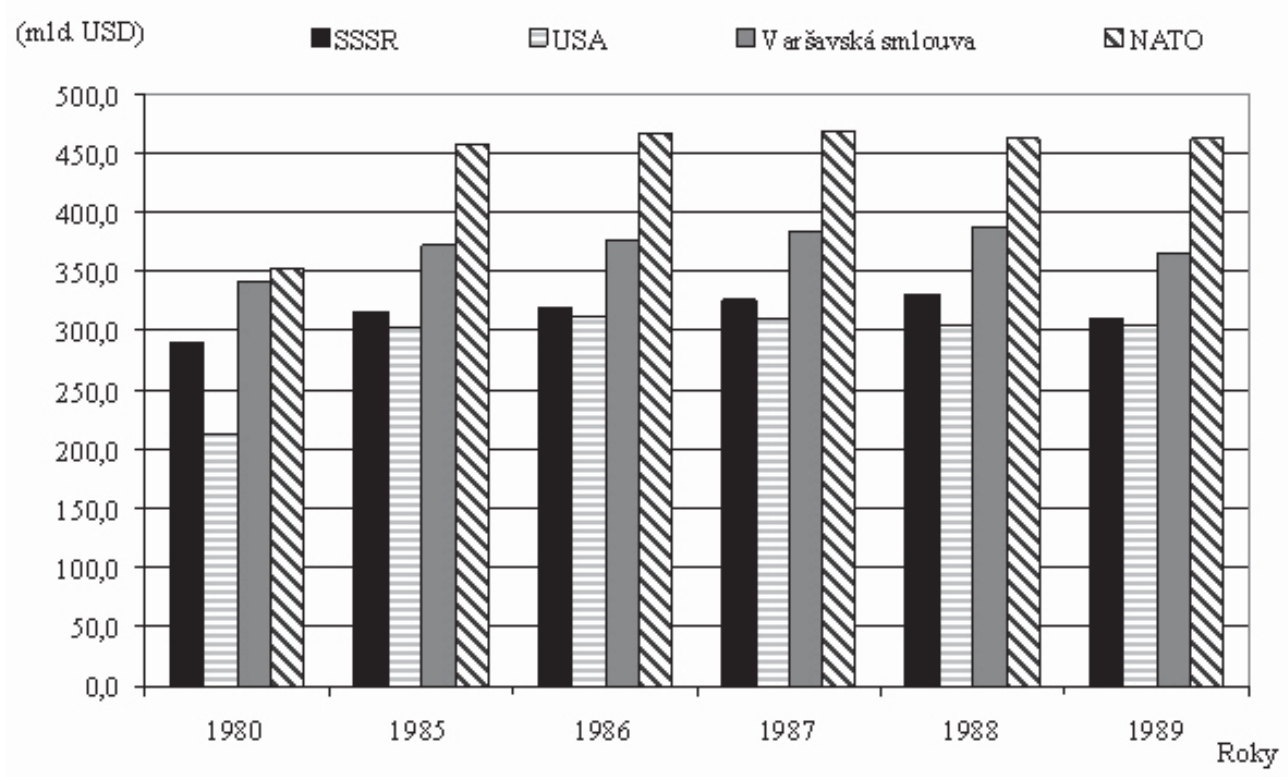

Zdroj: KREJČÍ, O.: Mezinárodní politika, str. 98, graf vytvořen na základě ve zdroji uvedených dat.

31 DURMAN, K.: Útěk od praporů, Kreml a krize impéria 1964-1991, str. 268.

32 PEREDERIJ, S. V.: "Perestrojka” v SSSR glazami sovetskich i amerikanskich avtorov. Opyt srovnitelnogo političeskogo issledovanija, str. 88-89.

33 DURMAN, K.: Útěk od praporů, Kreml a krize impéria 1964-1991, str. 314, 366, 477. 


\section{Disent a liberální intelektuálové}

Lidé náležící do této skupiny se rekrutovali především z centrálních univerzit a institutů, z lidí, co měli př́stup k Mezinárodnímu oddělení ÚV KSSS, novinářů, vysokopostavených úředníků ministerstev zahraničí a zahraničního obchodu. ${ }^{34}$ Oni se mohli seznámit se zaostáváním SSSR za Západem. Zpočátku byli přívrženci změn prováděných Gorbačovem. Reformátoři si totiž v roce 1987 uvědomili, že je čeká Chruščovův osud, pokud nezískají podporu zdola. ${ }^{35}$ Začali tedy provádět demokratizaci doprovázenou glasností (veřejnou informovaností). Avšak zahájení těchto procesů umožnilo vznik a především projevování se opozice. Na jedné straně vznikla opozice odsuzující započaté změny, tu reprezentovala především byrokracie. Na druhé straně vznikla radikální opozice, která si přála rychlejší a důslednější změny. Právě ta se vytvářela v prostředí liberálních intelektuálů a disentu. Za všechny disidenty bych zmínil fyzika A. Sacharova, který vzdoroval sovětským autoritám, prosazoval lidská práva a odzbrojení již za L. I. Brežněva. ${ }^{36}$

\section{Aktéři paralelní ekonomiky}

Stav oficiální ekonomiky se zhoršoval a ta se v roce 1989 ocitla v horším stavu, než v jakém byla $\mathrm{v}$ roce 1985 . Odhaduje se, že v létě roku 1990 bylo prodáno mimo oficiální distribuční cesty $42 \%$ masných produktů, 55 \% zeleniny, $20 \%$ mléka, 75 \% brambor, 44 \% vajec. ${ }^{37}$ Toto posilování paralelní ekonomiky bylo samozřejmě spojeno také s rostoucím vlivem jejich aktérů, kteří se stávali stále schopnějšími chránit a prosazovat své zájmy. Vzhledem k užitkům plynoucích z aktivit paralelní ekonomiky byli napojeni (možná často totožni) s osobami začleněnými v nomenklatuře, byrokracii, mafii.

Gorbačovovy reformy nabíraly stále výrazněji kurz od direktivního plánování reálného socializmu k induktivnímu plánování či tržnímu hospodářství v podobě sociálně-demokratického uspořádání. To se zpočátku nesetkávalo s prŕlišnými sympatiemi aktérů paralelní ekonomiky, kteří se obávali ztráty svého privilegovaného postavení. Brzy však pochopili, že destabilizace systému spojena s tímto přechodem, který nebyl ze strany státu př́liš dobře prováděn, jim umožní upevnění a legalizaci jimi získaných pozic a zisků. To se mělo provést pod rouškou demokratizace, doprovázené zbavením se KSSS, KGB a dalších institutů socialistického režimu. ${ }^{38}$

Byrokracie byla jasným odpůrcem reforem, nebo $\mathrm{v}$ nich viděla příčinu ztráty svých pozic a výhledově riziko odhalení zbytečnosti své existence. Přesto i ona ztrácela půdu pod nohama a přestávala mít rozhodující vliv na události, které se stále více řítily neřizeně kupředu směrem k pádu centrálně plánované ekonomiky i SSSR. Vládnoucím strukturám začalo být jasné, že svou moc si mohou udržet jedině tehdy, jestliže začnou řídit doposud státní majetek na základě práva soukromého vlastnictví. ${ }^{39}$ Vzhledem $\mathrm{k}$ napojení těchto struktur na aktéry paralelní ekonomiky je pak jasné, jak morálně pochybná byla východiska

34 KRASILSCHIKOV, V. A.: Vdogonku za prošedšim vekom: Razvitie Rossii v XX veke s točki zrenija mirovych modernizacij, str. 217.

35 GORBAČOV, M. - MLYNÁŘ, Z.: Reformátoři nebývaji š astni - Dialog o „,perestrojce“, Pražském jaru a socialismu, str. 54.

36 DEUDNEY, D. - IKENBERRY, J.: The International Sources of Soviet Change, str. 110.

BOETTKE, P. J.: Why Perestroika failed. The Politics and Economics of Socialist Transformation. str. 41.

KRASILSCHIKOV, V. A.: Vdogonku za prošedšim vekom: Razvitie Rossii v XX veke s točki zrenija mirovych modernizacij, str. 218.

39 ZHUKOV, V. I.: Rossijkie preobrazovanija: sociologija, ekonomika, politika, str. 33. 
hospodářských reforem v SSSR a cesty jeho ekonomiky k legálním tržním vztahům. Snahy těchto struktur o ovládnutí hospodářské základny byly zcela jistě ulehčeny probíhající regionalizací ekonomiky.

\section{Vybrané kroky Gorbačovského vedení}

\section{Protialkoholová kampaň}

V sovětské společnosti byl alkoholizmus vnímán jako stále závažnější problém. Za negativní dopady alkoholizmu jsou považovány především kriminalita, dopravní nehody, pracovní úrazy, snížení produktivity práce, snížení iniciativy jedinců, snížení úspor domácností, celá řada zdravotních problémů, vyšší rozvodovost, nižší porodnost apod. Na jedné straně snižuje produktivitu hospodářského systému, na druhé straně vytváŕí pro systém ještě dodatečné náklady. Počet notorických alkoholiků byl v SSSR asi 5 milionů a AV SSSR odhadovala roční ztráty způsobené alkoholizmem na $80-100$ miliard rublů. ${ }^{40}$ Dáme-li tento údaj do poměru

k HNP v běžných cenách za rok 1985, ${ }^{41}$ odpovídaly ztráty 10, 3-12,9\% HNP. Výroba alkoholu byla také značnou zátěží pro neefektivně fungující zemědělství. V sedmdesátých letech bylo na oficiální výrobu alkoholu využíváno $3 \%$ čisté sklizně obilí, $6 \%$ brambor, $6 \%$ cukrové řepy a $60 \%$ melasy. ${ }^{42}$

Protialkoholická kampaň, o které jednalo politbyro 6. dubna 1985, se tedy pokoušela vyřešit tento závažný problém státními nařízeními. Na kampaň však nelze nahlížet izolovaně, navazovala na více či méně neúspěšné snahy snížit spotřebu alkoholu v SSSR za N. S. Chruščova i L. I. Brežněva. Problém alkoholizmu byl ještě prohlouben cenovou reformou z roku 1983, kterou byla zlevněna vodka. Ta byla nazývána jako ,andropovka“ podle tehdejšího generálního tajemníka J. V. Andropova. Prohibice jako taková však byla v minulosti neúspěšná nejen ve Spojených státech amerických, ale i v carském Rusku. Cílem kampaně bylo odstranit následek, nikoliv př́ičinu alkoholizmu. Průměrná domácnost vydávala na alkohol $10-15 \%$ svých příjmů. ${ }^{43}$ Prríjmy z prodeje alkoholu byly jedním ze základních a nejstabilnějších př́ijmů sovětského rozpočtu. Svou funkci musel opustit ministr financí V. F. Garbuzov, který si uvědomoval rizikovost takového kroku a varoval před ním. První kroky byly učiněny v květnu 1985 a v září byl radou ministrů vydán dekret, který vedl k postupné redukci výroby destilovaných alkoholických nápojů a vinných produktů, odnímání licencí na prodej alkoholu mnoha restauracím a snížení množství prodávaného alkoholu v maloobchodě, koncentraci prodeje alkoholu do malého počtu prodejen. ${ }^{44}$ Důchod z prodeje alkoholu tvořil zhruba $15 \%$ př́ijmů státního rozpočtu, avšak po spuštění reformy tyto př́́jmy klesly v letech 1986 - 1987 na 3-4 \%. ${ }^{45}$

To, že kroky této kampaně byly dováděny, až do absurdna dokazuje, že bylo v letech 1985-1988 vykáceno 364 tis. ha vzácných vinohradů, což tvořilo 28, 8 \% jejich celkové plochy. ${ }^{46}$ Je zřejmé, že i taková opatření, která sama o sobě znamenala ztráty, byla spojena $\mathrm{s}$ dalšími dodatečnými náklady. Na plochách po vinohradech bylo nutné vysadit jiné plodi-

40 DURMAN, K.: Útěk od praporio, Kreml a krize impéria 1964-1991, str. 303.

41 JASIN, E. G.: Rossijskaja ekonomika. Istoki i panorama rynočnych reform, str. 104.

42 TREML, V. G.: Alcohol in the USSR: A Fiscal Dilemma, str. 163.

43 TARSCHYS, D.: The Success of a Failure: Gorbachev's Alcohol Policy, 1985-88, str. 12.

44 TARSCHYS, D.: The Success of a Failure: Gorbachev's Alcohol Policy, 1985-88, str. 11.

45 JASIN, E. G.: Rossijskaja ekonomika. Istoki i panorama rynochnykh reform, str. 81.

46 SADRIEV, M. M. - SAFAROV, T. A.: Ideologija politiki socialno-ekonomičeskich reform v Rossi, str. 28. 
ny, $\mathrm{v}$ továrnách doposud vyrábějící alkoholové nápoje bylo nutné zavést jinou výrobu, nakoupit jiné stroje apod.

Limitujícím faktorem každého předchozího omezování spotřeby alkoholu v SSSR byla poměrně snadná výroba domácího destilátu - samohonky. Výroba tohoto destilátu byla nenáročná na prostor, dovednosti, vybavení a potřebné suroviny byly zpravidla dostupné (brambory, obilí, cukr, cukrová řepa, nebo ovoce). ${ }^{47}$ Přestože byla samohonka především venkovským fenoménem $\mathrm{v}$ době omezování oficiální nabídky alkoholu se objevovala i ve městech a její cena se odvíjela především od dostupnosti a ceny zemědělských produktů, ceny a dostupnosti alkoholu v obchodech a účinnosti státní represe. ${ }^{48}$ Význam pálení samohonky dokazuje, že po spuštění protialkoholické kampaně se stal cukr okamžitě nedostatkovým zbožím. ${ }^{49}$ Od nelegální domácí výroby neodradily lidi ani poměrně vysoké tresty, které za to hrozily. Např. trestní zákoník z roku 1962 stanovil za destilaci pro komerční užití trest odnětí svobody na jeden až tři roky, u destilace pro vlastní potřebu odnětí svobody až na jeden rok nebo pokutu do výše až 300 rublů. Kupujícímu samohonky hrozila pokuta ve výši 50 rublù ${ }^{50}$ Počet výrobců nelegálního alkoholu vzrostl z 80000 (v roce 1985), na 150000 (v roce 1986), 397.000 (v roce 1987). ${ }^{51}$

V. G. Treml z Duke University se domnívá, že samohonka nebyla substitutem pro koňak a sekt. ${ }^{52}$ Obecně řečeno se domnívá, že samohonka je dobrým substitutem jen pro tvrdý alkohol jako vodka apod. Tento předpoklad je však chybný, nebo v době prohibice dochází naopak k př́iklonu k tvrdému alkoholu, nebo k dosažení „stavu opojení“ je dostatečné nižší množství takového alkoholového nápoje, což snižuje především riziko dopadení represivními orgány. To, že substitutem alkoholických nápojů mohou být i jiné látky dokazuje, že lidé řešili nedostatek alkoholu tak nebezpečnými způsoby jako užíváním průmyslového alkoholu, mycích prostředků a narkotik. Protialkoholická kampaň se stala podpůrným krokem rozvoje paralelní ekonomiky v oblasti prodeje a výroby lihovin a i nebezpečnějších návykových látek. Právě v tomto období dochází v paralelní ekonomice k určitému zostřování a na jejím základě dochází podle některých autorů k formování organizovaného zločinu v SSSR. ${ }^{53}$

\section{Uvolněná měnová politika}

Protialkoholická kampaň tedy snížila výrazně př́ijmy státního rozpočtu. S obdobím perestrojky je ovšem spojen také pokles cen ropy na světových trzích, který způsobil další snížení př́ijmů rozpočtu. To vedlo k deficitům státního rozpočtu SSSR, který byl poprvé oficiálně přiznán v roce 1988, přestože se fakticky objevil mnohem dř́ve. Samotný deficit by ještě nemusel být až tak závažným problémem, kdyby nebyl financován př́mým úvěrováním Státní bankou, ${ }^{54}$ tj. bankou s emisní funkcí hotovostních peněz. Např. v roce 1988 bylo dáno do oběhu $4 \mathrm{x}$ více peněz, než jaký byl roční průměr v předchozí pětiletce. ${ }^{55}$ Toto chování mohlo mít podle ekonomických zákonitostí jediný dopad a tím bylo propuknutí in-

47 TREML, V. G.: Alcohol in the USSR: A Fiscal Dilemma, str. 167.

48 TREML, V. G.: Alcohol in the USSR: A Fiscal Dilemma, str. 168.

49 DURMAN, K.: Útěk od praporů, Kreml a krize impéria 1964-1991, str. 304.

50 TREML, V. G.: Alcohol in the USSR: A Fiscal Dilemma, str. 169.

51 TARSCHYS, D.: The Success of a Failure: Gorbachev's Alcohol Policy, 1985-8, str. 20.

52 TREML, V. G.: Alcohol in the USSR: A Fiscal Dilemma, str. 173.

53 ZHUKOV, V. I.: Rossijkie preobrazovanija: sociologija, ekonomika, politika, str. 34.

54 POPOV, V. - SCHMELEV, N.: Sovetskaja ekonomika: ot plana k rynku, str. 157.

55 SUSLOV, JU. P.: Radikalnye peremeny v SSSR (1985-1991 gg.), str. 6. 
flace. Růst peněžní zásoby spolu se stálostí cen v oficiální ekonomice měly za následek prohlubování deficitu v SSSR.

Prohlubování deficitu v oficiální ekonomice bylo dalším impulzem pro paralelní ekonomiku. Jaké však byly dopady existence paralelní ekonomiky na inflaci? Mírnila skutečně paralelní ekonomika inflační tlaky prostřednictvím vyšších cen? Nebo je pravdivé, že aktivita $\mathrm{v}$ paralelní ekonomice přinášela osobám dodatečné finanční zdroje a přispívala tak $\mathrm{k}$ inflaci, jak se domnívá O'Hearn. ${ }^{56}$

Princip vzniku inflace se pokusím vysvětlit s pomocí modelu postaveného na dvou upravených Fisherových rovnicích. ${ }^{57}$ Uvolněná měnová politika vedla k růstu peněžní zásoby $\left(\Delta \mathrm{M}^{\mathrm{S}}\right)$. Její část směřující do oficiální ekonomiky zůstávala nezměněna $\left(\mathrm{M}_{\mathrm{O}}^{\mathrm{S}}\right)$, její nárůst se neprojevil ani v růstu reálného produktu oficiální ekonomiky $\left(\mathrm{Y}_{\mathrm{O}}\right)$, který byl minimálně konstantním díky ekonomické stagnaci, ani v cenové hladině $\left(\mathrm{P}_{\mathrm{O}}\right)$, která byla konstantní a státem určena. Nutně se tedy v oficiální ekonomice neměnila ani rychlost obratu peněz $\left(\mathrm{V}_{\mathrm{O}}\right)$.

- růst peněžní zásoby:

$\Delta \mathrm{M}^{\mathrm{S}}=\mathrm{M}_{\mathrm{O}}^{\mathrm{S}}+\Delta \mathrm{M}_{\mathrm{P}}^{\mathrm{S}}$

- rovnice oficiální ekonomiky: $\quad \mathrm{M}_{\mathrm{O}}^{\mathrm{S}} \cdot \mathrm{V}_{\mathrm{O}}=\mathrm{P}_{\mathrm{O}} \cdot \mathrm{Y}_{\mathrm{O}}$

- rovnice paralelní ekonomiky: $\Delta \mathrm{M}_{\mathrm{P}}^{\mathrm{S}} \cdot$ ? $\mathrm{V}_{\mathrm{P}}=\Delta \mathrm{P}_{\mathrm{P}} \cdot \Delta \mathrm{Y}_{\mathrm{P}}$

- produkt paralelní ekonomiky: $\quad \mathrm{Y}_{\mathrm{P}}=\mathrm{n} . \mathrm{Y}_{\mathrm{O}}+\mathrm{Y}_{\mathrm{X}}$

Růst peněžní zásoby se tak plně projevil v paralelní ekonomice $\left(\Delta \mathrm{M}_{\mathrm{P}}^{\mathrm{S}}\right)$. Tam mohl být nárůst peněžní zásoby po určitou dobu zmírňován růstem reálného produktu této ekonomiky $\left(\Delta \mathrm{Y}_{\mathrm{P}}\right)$. Do reálného produktu paralelní ekonomiky jsem zahrnul část oficiálního produktu ( $\mathrm{n}$. $\left.\mathrm{Y}_{\mathrm{O}}\right)$, se kterým bylo v paralelní ekonomice spekulováno, a část produktu prímo vznikajícího v této ekonomice $\left(\mathrm{Y}_{\mathrm{X}}\right)$. Tlak na zvyšování množství statků $\mathrm{z}$ oficiální ekonomiky, se kterým bylo spekulováno se brzy zastavil na nemožnosti již vyššího odčerpávání a na zvyšování rizikovosti takového odčerpávání pro prodávající. Vývoj rychlosti obratu peněz $\left(\Delta \mathrm{V}_{\mathrm{P}}\right) \mathrm{v}$ paralelní ekonomice není zcela jednoznačný. Domnívám se, že docházelo spíše k jejímu poklesu. Na tom se podílel jednak masivní růst peněžní zásoby a to, že peněžní transakce byly prováděny stále častěji v zahraničních „tvrdých“ měnách. To znamenalo, že klesající rychlost obratu peněz mohla do určité míry snižovat tlak na růst cenové hladiny. Vliv zvyšování peněžní zásoby v důsledku nezodpovědné měnové politiky se tak rozděloval mezi pokles rychlosti obratu peněz a růst cenové hladiny $\left(\Delta \mathrm{P}_{\mathrm{P}}\right)$, tj. inflaci. Inflace nebyla $\mathrm{v}$ zemích reálného socializmu skrytá, ale plně se projevovala právě v paralelní ekonomice.

Paralelní ekonomika, především díky spekulování, měla také funkci přerozdělování zdrojů mezi aktéry. Toto přerozdělování však způsobilo, že určité skupiny aktérů paralelní ekonomiky naakumulovaly takové sumy peněz, že za ně mohly koupit statky běžným občanům nedostupné, které např̀. mohly být nelegálně prodány na západních trzích se ziskem ve valutách. Rigidita cen oficiální ekonomiky způsobovala přerozdělování národního bohatství a sociální diferenciaci. Schéma bylo podle mého následující:

- lidé si za utrženou mzdu nemohli koupit zboží v oficiální ekonomice kvůli existujícímu deficitu,

- k jeho pořízení tedy došlo v paralelní ekonomice avšak za vyšší cenu (tj. zahrnující jakousi rizikovou prémii pro prodávajícího),

56 O'HEARN, D.: The Consumer Second Economy: Size and Effect, str. 230.

57 Za konzultaci tohoto modelu bych chtěl poděkovat paní doc. Ing. Evě Kindlové, CSc. z Katedry ekonomie NF VŠE v Praze. 
- prodávající tímto způsobem získal určitou sumu rublů, od které musel odečíst náklady spojené s obstaráním deficitního zboží,

- stále mu však zůstával zisk, který mohl využít k úplatkům, díky kterým se pro něj stávalo normálně deficitní zboží dostupným, nebo ho mohl směnit za valuty, či proměnit do takových statků jako je zlato, diamanty apod.

\section{Podnikatelská činnost}

Jak vyplývá z již zmíněné existence paralelní ekonomiky, soukromá podnikatelská činnost nebyla v SSSR nikdy zcela potlačena. Tento fakt se velmi silně již před začátkem perestrojky projevoval v zemědělství. Osobám pracujícím v zemědělství bylo umožněno pracovat na malé části půdy. Tato půda sice nebyla jejich vlastnictvím, ale pro ně byla cennější možnost prodávat svou produkci za tržní ceny jiným osobám než státu. Přesto docházelo k občasným pokusům státu do těchto cen zasahovat. ${ }^{58}$ Vzhledem k tomu, že státem ovládané zemědělské podniky nebyly schopny zajistit dostatečnou produkci, musel být režim těchto „soukromých zemědělcư “ respektován, přestože poněkud zaváněl kapitalizmem. Uvádí se, že 3/4 prodávaného masa pocházela ze zvířat vykrmených dovezeným obilím, ${ }^{59}$ vycházelo že každá třetí houska a každé druhé balení makaronů bylo zahraničního původu. ${ }^{60}$ Produktivita práce v zemědělství odpovídala $20 \%$ americké, každý sovětský pracovník v zemědělství dokázal zajistit potraviny pro 11 lidí zatímco v USA pro 80 lidí. ${ }^{61}$ To jasně dokazuje v jak otřesném stavu bylo sovětské zemědělství a jak bylo postiženo neefektivností, kterou však bylo jako infekcí zasažené celé hospodářství.

Ústava a jiné právní normy umožňovaly občanům vlastnictví majetku využitelného pro hospodářskou činnost, pokud ovšem jeho vlastník nezískával z jeho užití „nevydělané““ prríjmy. To v praxi znamenalo, že prŕípadného podnikání se mohli účastnit jen rodinní příslušníci

a zároveň muselo být podnikání tolerováno místními úřady. Do poloviny osmdesátých let byly za legální soukromé podnikatelské aktivity považovány především drobné řemeslné práce. Avšak na rozdíl od činnosti farmářů neměla tato činnost významný hospodářský dopad. ${ }^{62} \mathrm{~V}$ prosinci 1986 došlo k rozšíření možností soukromého podnikání. Přestože se doposud nedalo hovořit o svobodném podnikání, byl to pokrok, který umožňoval prostřednictvím zákona o individuální pracovní činnosti drobnou produkci spotřebního zboží, prodej služeb (opravárenské služby, taxislužba), možnost provozování rodinných hotelů a restaurací. Stále platila omezení spojená s nutností souhlasu místních úřadů a rodinnou podobou takového podnikání. ${ }^{63}$

V červnu 1987 Nejvyšší sovět přijal zákon o státním podniku, to fakticky znamenalo pokus o nahrazení dosavadního direktivního plánování induktivním. Tento zákon umožňoval vstupovat podnikům do smluvních vztahů mezi sebou i se státem. Předpokládalo se, že se zákon bude v roce 1988 vztahovat na jednu polovinu podniků a od dalšího roku i na zbývající polovinu. Tato právní norma korespondovala se snahou zavést tzv. tržní socializmus, který by byl založen na třech předpokladech: samofinancování, samořízení, samonávrat-

58 STEPHAN, P. B. III: Perestroyka and Property: The Law of Ownership in the Post-Socialist Soviet Union, str. 41.

59 TIMOFEEV, T. T.: Perestrojka i sovremennyj mir, str. 52.

60 POPOV, V. - SCHMELEV, N.: Sovetskaja ekonomika: ot plana k rynku, str. 100.

61 SUSLOV, JU. P.: Radikalnye peremeny v SSSR (1985-1991 gg.), str. 12.

62 STEPHAN, P. B. III: Perestroyka and Property: The Law of Ownership in the Post-Socialist Soviet Union, str. 42.

63 STEPHAN, P. B. III: Perestroyka and Property: The Law of Ownership in the Post-Socialist Soviet Union, str. 49. 
nost (rentabilita). ${ }^{64}$ Po splnění objednávky od státu mohly podniky zbývající část výrobků prodat na trhu za ceny odpovídající poptávce. To ovšem vedlo podniky k omezování výroby levnějšího zboží a zvyšování ceny ostatních. ${ }^{65}$

Již byla zmíněna monopolní struktura sovětské ekonomiky, to mělo vliv i na velikost podniků, které byly jedny z největších na světě. Podniky do 200 zaměstnanců tvořily v SSSR jen 5,3\% z celkového objemu, zatímco na Západě tvořily 30 až $50 \%$. ${ }^{66}$ Monopolizací byl postižen i zahraniční obchod, kdy dovozní a vývozní operace byly centralizovány do ministerstva zahraničního obchodu. Tím došlo k odtržení nákupů a prodejů od výrobců. Od roku 1986 byly činěny kroky k decentralizaci zahraničního obchodu, avšak nejdůležitější exportní artikl - ropa zůstával nadále v rukou centra ${ }^{67}$ SSSR se snažil hospodářství otevřít zahraničním partnerům a přilákat jejich zdroje. Vznikla myšlenka o zakládání společných podniků v oblasti služeb, stavebnictví a dopravy, do kterých bylo sovětským vedením vítáno zapojení západních podnikatelů. ${ }^{68} \mathrm{Na}$ konci roku 1986 byly vládou vybrány podniky, kterým bylo umožněno př́mo komunikovat se západními partnery. V prosinci 1988, po dvou zkušebních letech, vláda radikálně rozšiŕila možnost přístupu sovětských podniků na zahraniční trhy a liberalizovala pravidla vzniku společných podniků. Zahraničním subjektům bylo umožněno ve společných podnicích získat majoritu a mít zahraničního ředitele. Přesto přetrvávala snaha vládních úřadů zachovat byrokratickou kontrolu nad zahraničním obchodem. Podle dekretu vydaného v březnu 1989 bylo po všech společných podnicích požadováno získání souhlasu ministerstva zahraničního obchodu, což opět dávalo tomuto úradu možnost mařit konkurenci a nadále chránit existenci zbývajících organizací zahraničního obchodu. ${ }^{69}$

\section{Tabulka č. 6: Vývoj počtu podnikatelů a zaměstnanců družstev}

\begin{tabular}{|c|c|c|}
\hline Rok & $\begin{array}{c}\text { Počet individuálních } \\
\text { podnikatelů }\end{array}$ & $\begin{array}{c}\text { Počet zaměstnanců } \\
\text { ve družstvech }\end{array}$ \\
\hline \hline 1986 & 100000 & - \\
\hline 1987 & 300000 & 15000 \\
\hline 1988 & 700000 & 150000 \\
\hline 1989 & 300000 & 1400000 \\
\hline 1990 & - & 4500000 \\
\hline
\end{tabular}

Zdroj: POPOV, V. - SCHMELEV, N.: Sovetskaja ekonomika: ot plana k rynku, str. 91.

Zákon o družstvech z jara roku 1988 legalizoval skutečnou soukromou hospodářskou činnost, nebo družstva mohla najímat práci, prodávat své podíly, zároveň nemusela mít souhlas k činnosti místních autorit. Musela se pouze registrovat a deklarovat, že předmět jejich činnosti není v rozporu s platným právem. Existovala i možnost přezkumu rozhodnutí u nadřízeného sovětu či soudu. ${ }^{70}$ Od družstev se očekávalo, že budou schopna pružně a rychle reagovat na změny poptávky a zmírní tak neustále přítomný deficit zboží. Avšak

64 SADRIEV, M. M. - SAFAROV, T. A.: Ideologija politiki socialno-ekonomičeskich reform v Rossii, str. 30.

65 DURMAN, K.: Útěk od praporü, Kreml a krize impéria 1964-1991, str. 344.

66 POPOV, V. - SCHMELEV, N.: Sovetskaja ekonomika: ot plana k rynku, str. 13.

67 POPOV, V. - SCHMELEV, N.: Sovetskaja ekonomika: ot plana k rynku, str. 162.

68 GORBAČOV, M. S.: Přestavba a nové myšlení pro naši zemi a pro celý svět, str. 148.

69 STEPHAN, P. B. III: Perestroyka and Property: The Law of Ownership in the Post-Socialist Soviet Union, str. 50-52.

70 STEPHAN, P. B. III: Perestroyka and Property: The Law of Ownership in the Post-Socialist Soviet Union, str. 52-53. 
některá družstva pojala svou podnikatelskou činnost jako nákup produkce státních podniků a jejich opětovný prodej za vyšší ceny. Toto spekulativní, i když přirozené, chování družstev bylo vnímáno značně negativně a Prezidium Nejvyššího sovětu v roce 1989 družstvům zakázalo prodávat jimi nevyráběné zboží, tj. bez provedené fyzické změny. ${ }^{71}$ To, že se pod pojmem socialistického družstva skrývalo soukromé podnikání, dokazuje i to, jak se vyvíjel počet členů družstev a jejich zaměstnanců. Na tři až pět členů družstva připadalo 150 až 200 zaměstnanců. ${ }^{72}$ Vedení SSSR považovalo za vhodnější tolerovat vznik nové tř́idy podnikatelů, než respektovat existenci a rozvoj mafie. Otázkou však zůstává nakolik se dá předpokládat, že se tato nová podnikatelská elita etablovala právě z aktérů paralelní ekonomiky, byrokracie, nomenklatury a členů mafie. To je těch, kteří měli př́stup $\mathrm{k}$ finančním zdrojům a informacím.

\section{Změny v zahraniční politice}

SSSR jakožto jedna ze dvou supervelmocí svými kroky jednoznačně ovlivňoval povahu mezinárodního systému. Ten definujeme jako množinu prvků, mezi kterými existují vztahy vzájemné interakce. ${ }^{73}$ Přijmeme-li předpoklad, že kvalita a kvantita zdrojů nutných pro zahraniční politiku a vojenské akce je nepřímo ovlivněna ekonomickou kapacitou ${ }^{74}$, poté je zřejmé, že od přelomu 70. a 80. let minulého století v SSSR tyto zdroje spolu s jeho ekonomickou kapacitou upadaly. Tím se snižovaly možnosti této velmoci realizovat své záměry prostř̌ednictvím zahraniční politiky. Nejenže hospodářská stagnace redukovala zdroje př́stupné zahraniční politice, ale snižovala legitimitu sovětské režimu doma a jeho atraktivitu jakožto modelu pro zahraničí. ${ }^{75}$ Tento efekt se projevoval především úpadkem vlivu marxistických a socialistických hnutí v západních zemích, která po celou dobu studené války fungovala jako ,pátá kolona“ SSSR. Na Západě se očekávalo, že SSSR by mohl na krizi zareagovat obnovením imperializmu (agresí) a autoritářstvím (domácími represemi). ${ }^{76}$ Agresi však sovětské vedení zavrhlo, nebo byla př́iliš nebezpečná a mohla by vést k rozpoutání jaderné (tj. sebevražedné) světové války. Nehledě na to, že pro SSSR byla jistě dostatečnou lekcí jeho neúspěšná angažovanost v Afghánistánu, kde měl v roce 1987 přes 100.000 mužů a udržování tohoto kontingentu jej stálo 5, 5 miliardy rublů. ${ }^{77}$

Tvrdé represe již v této době nebyly možné. Stále výrazněji upadal monopol KSSS na moc. Na scéně se objevovaly nové již zmíněné vlivové skupiny, které by se o svou moc nedaly jednoduše připravit a ohrozily by postavení samotného sovětského vedení. Vzhledem k rozvoji moderních informačních a komunikačních technologií nebylo již možné izolovat SSSR od zbytku světa, jako tomu bylo dříve v případě Číny, Japonska či stalinistického období SSSR. ${ }^{78}$ Dá se říct, že pro obyvatelstvo žijící ve velkých sovětských městech došlo již v 70. letech 20. století k zaměnění tehdejší železné opony za skleněnou, přes kterou ,nahlíželi“" na Západ. ${ }^{79}$ Byl tu také nezanedbatelný vliv mezinárodních organizací, kterých byl SSSR členem, či které hodnotily jeho reálie (např. úroveň dodržování lidských práv - 
Amnesty International, Helsinky Watch). Nezanedbatelným byl také společensko-kulturní vliv Západu (tj. vítězství Coca-Coly, modrých džín) na sovětskou společnost, což je pokládáno za součást tzv. občanské diplomacie (citizen diplomacy) ${ }^{80}$. Z předešlých argumentů vyplývá, že Gorbačov vybral nejracionálnější cestu, tj. pokus o přestavbu SSSR. Ta mohla skončit bud' úspěšným dosažením cíle a nebo zhroucením celé velmoci.

Př́istup USA k SSSR se značně přitvrdil nástupem Reaganovy administrativy do Bílého domu na počátku 80. let. Příznakem ukončení období uvolňování byly spory mezi USA a SSSR o rozmístění raket SS-20 a Pershing II v Evropě. Propagandistickým krokem bylo označení SSSR za „ř́iši zla“. Reaganova administrativa, která začala považovat dosavadní politiku zadržování za př́liš měkkou k SSSR, se snažila přejít k politice vytlačování. ${ }^{81}$ Došlo k vyhlášení Reaganovy doktríny, která kladla důraz na náskok v technologiích nad SSSR. Nejrazantněji byla pojata v programu Strategické obranné iniciativy vyhlášené 23. března 1983, který je nazýván programem „hvězdných válek“. Tato strategie byla obhajována tím, že SSSR na ní nebude schopen vzhledem ke své slabosti v technologiích reagovat, ${ }^{82}$ což by následně vedlo k narušení bezpečnostního dilematu ${ }^{83}$ a vojenské dominanci USA. Deklarovaná tvrdá linie americké zahraniční politiky však přispěla k vytvoření silných mírových hnutí v samotných USA a v západní Evropě. Avšak tvrdý postoj Bílého domu nelze chápat absolutně, nebo docházelo i k upřednostňování krátkodobých ekonomických a vnitropolitických zájmů. Právě administrativa R. Reagana zrušila J. Carterem zavedené embargo na vývoz obilí do SSSR, čímž republikánská strana dodržela slib středozápadním farmářủm. ${ }^{84}$ Je nutné si uvědomit, že ani Reagan v té době neměl ve svém tvrdém kurzu plnou podporu, na sovětské velvyslanectví ve Washingtonu přicházeli vyjádřit svůj nesouhlas nejen liberálové jako Edward Kennedy, ale i lidé z prezidentovy strany jako tehdejší viceprezident George Bush. ${ }^{85}$ Právě nástup George Bushe do funkce prezidenta USA znamenal pro Gorbačova zjednodušení situace. Bush byl politický praktik, kterého děsila možnost radikálních změn a které odmítal podporovat. ${ }^{86}$ Tento smírlivý př́stup amerického prezidenta spolu s oblibou Gorbačova v zahraničí vytvářely pozitivní předpoklady pro kladné vnímání SSSR ve světě. Konzervativní př́ístup Bushovy administrativy se plně projevil 16. ledna 1989, kdy H. Kissinger v Moskvě nabízel s podporou Bushe i ministra zahraničí Bakera jakousi Jaltu II, která by vycházela z respektu globální rovnováhy a kdy se USA zavazovaly neučinit nic, co by urychlovalo změny na Východě. Gorbačov tuto nabídku odmítl, nebo se zcela nereálně domníval, že socialistické společenství je možné udržet dobrovolnou cestou a že je výsledkem svobodné volby národů. ${ }^{87}$

Avšak postoj SSSR k jeho satelitům ve středovýchodní Evropě se měnil. SSSR ovlivňoval kroky a vývoj v těchto státech, k čemuž mu sloužily i organizace typu Varšavské smlouvy či Rady vzájemné hospodářské pomoci (tj. prakticky sovětské „úruady“ pro řízení armád a ekonomik vazalských států). V řadě těchto zemí byly u moci osoby, jejichž pozice se odvíjela od nezbytné podpory Moskvy a které byly připraveny plnit pokyny na základě dosud platné Brežněvovy doktríny. Tato doktrína vycházela z tzv. socialistického mezinárodního práva a opravňovala $\mathrm{k}$ intervencím $\mathrm{s}$ cílem zachování ideologické homogenity

80 DEUDNEY, D. - IKENBERRY, J.: The International Sources of Soviet Change, str. 113.

81 DEUDNEY, D. - IKENBERRY, J.: The International Sources of Soviet Change, str. 87.

82 DEUDNEY, D. - IKENBERRY, J.: The International Sources of Soviet Change, str. 95-96.

83 Pojem realizmu v mezinárodních vztazích označující proces, kdy stát učiní opatření ve snaze zvýšit svou bezpečnost, tím však zároveň sníží bezpečnost druhého státu. Druhý stát se cítí ohrožen a reaguje protiopatřením, které zase snižuje bezpečnost státu prvního. A tak se to neustále opakuje.

84 DEUDNEY, D. - IKENBERRY, J.: The International Sources of Soviet Change, str. 88.

85 DURMAN, K.: Útěk od praporů, Kreml a krize impéria 1964-1991, str. 262.

86 DURMAN, K.: Útěk od praporů, Kreml a krize impéria 1964-1991, str. 399, 403.

87 DURMAN, K.: Útěk od praporů, Kreml a krize impéria 1964-1991, str. 400-401. 
mezi satelity. ${ }^{88}$ Ve druhé polovině 80 . let však měl SSSR tolik vnitřních problémů, že neměl dostatek sil na ovlivňování vývoje v těchto zemích a Brežněvova doktrína byla nahrazena tzv. Sinatrovou doktrínou. ${ }^{89}$ Tento pojem je spojen s odmítnutím dosavadní praxe, kdy byla omezena suverenita satelitů a byla tvrdě potlačována jakákoliv odchylka od sovětského vzoru při budování socializmu. Politbyro již v roce 1985 přijalo zásadu, že se socialistickými zeměmi se musí jednat jako s rovnými. ${ }^{90}$ Bylo tedy otázkou, kdy se projeví napětí a latentní odpor $\mathrm{k}$ vůdcům $\mathrm{v}$ těchto zemích a jakým směrem se tyto státy vydají. Tito vůdci se však také stali představiteli konzervativní opozice vůči novému sovětskému vedení. Rychlý kolaps těchto režimů byl sovětským vedením zcela určitě nechtěný a neočekávaný, Gorbačov se byl ochoten vzdát nárazníkového pásma ve středovýchodní Evropě, ale počítal s tím, že Západ nebude do tohoto prostoru vojensky postupovat. ${ }^{91}$ Gorbačovovi je jeho konzervativními odpůrci vytýkáno, že nechal svému osudu tyto vazalské státy, které však zároveň byly nejbližšími spojenci SSSR. Tito kritici namítají, že se mělo začít se zlepšováním vztahů s nejbližšími spojenci, poté západní Evropou (Francií a západním Německem), Japonskem, Č́nou, Indií a zlepšením americko-sovětských vztahů se mělo končit. ${ }^{92}$ Začít od Evropy navrhoval i duchovní vůdce politiky glasnosti A. N. Jakovlev, ale Gorbačov se držel americko-sovětské linie stanovené již A. Gromykem. ${ }^{93}$

\section{Závěr}

Z práce vyplývá, že SSSR se ve druhé polovině 80 . let nalézal v tak obtížné hospodářské situaci, že změna se stala nutností. Snaha sovětského vedení postupnými kroky zlepšit stav sovětského hospodářství a tím zvýšit blahobyt obyvatelstva přiváděla naopak zemi do stále obtížnější hospodářské i vnitropolitické situace. Výrazně se projevil negativní důsledek spoutání společenských věd ideologickými dogmaty po dobu sedmdesáti let. Ty nebyly vždy schopny vytvořit odpovídající analýzy dopadů prováděných opatření. Druhou stranou mince bylo, že ne vždy byla na straně politických vůdců ochota názorům vědy, nejen té ekonomické, naslouchat.

Vládnoucí elity ve snaze udržet si postavení a zachránit SSSR byly ochotny opustit i charakteristické atributy tohoto státu - ideologii marxizmu-leninizmu, centrálně plánované hospodářství a soupeření se Západem. Prohlubující se hospodářské problémy odhalily skutečnost, že existence SSSR byla jen důsledkem hrozby síly, strachu a neřešení národnostních problémů. Jakmile došlo k oslabení pozice centra, své role se s různými cíli ujímali vůdci v jednotlivých republikách a regionech. Stejně tak nelze vidět pád sovětského impéria jako výsledek Reaganovy politiky. I když tomuto pádu výrazně přispěla a zřejmě jej urychlila, nebo odčerpala sovětským vůdcům čas a prostředky. K pádu SSSR však přispěly vnitřní problémy, které vyplynuly z hospodářské slabosti SSSR, jeho neschopnosti nadále hrát roli velmoci a udržet nejen své impérium, ale ani svou státnost.

88 SEIDL-HOHENVELDERN, I.: Mezinárodní právo veřejné, str. 134.

89 Pojem Sinatrova doktrína vznikl jako vtipná poznámka mluvčího ministerstva zahraničí SSSR G. Gerasimova v Helsinkách na změnu sovětského přístupu k satelitům, kdy se tyto země mohly chovat v souladu s textem písně F. Sinatry My Way, tj. podle hesla „I did it my way“. Tato poznámka ho ovšem stála místo mluvčího.

90 DURMAN, K.: Útěk od praporů, Kreml a krize impéria 1964-1991, str. 320.

91 DEUDNEY, D. - IKENBERRY, J.: The International Sources of Soviet Change, str. 90

92 KRASILSCHIKOV, V. A.: Vdogonku za prošedšim vekom: Razvitie Rossii v XX veke s točki zrenija mirovych modernizacij, str. 224.

93 DURMAN, K.: Útěk od praporů, Kreml a krize impéria 1964-1991, str. 310-311. 


\section{Literatura}

[1] BOETTKE, P. J.: Why Perestroika failed. The Politics and Economics of Socialist Transformation. London and New York: Routledge, 1992, 199 p. URL: http://economics.gmu.edu/pboettke/pubs/Why_Perestroika_Failed.pdf [20.2. 2006]

[2] DEUDNEY, D. - IKENBERRY, J.: The International Sources of Soviet Change, in: International Security, Vol. 16, Winter 1991-1992, No. 3, pp. 74-118. URL: http://links.jstor.org/sici?sici=0162-2889\%28199124\%2F199224\%2916\%3A3\%3C 74\%3ATISOSC\%3E2.0.CO\%3B2-5 [31. 10.2006]

[3] DRULÁK, P. - DRULÁKOVÁ, R.: Tvorba a analýza zahraniční politiky. Praha: Vysoká škola ekonomická v Praze, 2000. 127 s. ISBN 80-245-0105-8

[4] DURMAN, K.: Útěk od praporů, Kreml a krize impéria 1964-1991. Praha: Karolinum, nakladatelství Univerzity Karlovy, 1998. 531 s. ISBN 80-7184-672-4

[5] EICHLER, J.: Mezinárodní bezpečnost na počátku 21. století. Praha: Ministerstvo obrany České republiky - AVIS, 2006. 301 s. ISBN 80-7278-326-2

[6] FELDBRUGGE, F. J. M.: Government and Shadow Economy in the Soviet Union, in: Soviet Studies, Vol. 36, 1984, No. 4, pp. 528-543. URL: http://links.jstor.org/ sici?sici $=0038-5859 \% 28198410 \% 2936 \% 3 \mathrm{~A} 4 \% 3 \mathrm{C} 528 \% 3 \mathrm{AGASEIT} \% 3 \mathrm{E} 2.0 . \mathrm{CO} \% 3$ B2-H [19. 3. 2006]

[7] GORBAČOV, M. - MLYNÁŘ, Z.: Reformátoři nebývají š astni - Dialog o „,perestrojce“, Pražském jaru a socialismu. Praha: Victoria Publishing, 1995. 207 s. ISBN 8085865-98-X

[8] GORBAČOV, M. S.: Přestavba a nové myšlení pro naši zemi a pro celý svět. Praha: Nakladatelství Svoboda, 1987. 231 s.

[9] CHECKEL, J.: Ideas, Institutions, and the Gorbachev Foreign Policy Revolution, in World Politics, Vol. 45, No. 2, 1993, pp. 271-300. URL: http://links.jstor.org/ sici?sici=0043-8871\%28199301\%2945\%3A2\%3C271\%3AIIATGF\%3E2.0.CO\%3 B2-A [31. 10. 2006]

[10] JASIN, E. G.: Rossijskaja ekonomika. Istoki i panorama rynočnych reform. Moskva: Gosudarstvennyj universitet Vyššaja škola ekonomiki, 2003, 437 s. ISBN 5-7598-0113-9

[11] KISSINGER, H.: Umění diplomacie. Od Richelieua k pádu Berlínské zdi. Praha: PROSTOR, 1999. 952 s. ISBN 80-7260-025-7

[12] KRASILSCHIKOV, V. A.: Vdogonku za prošedšim vekom: Razvitie Rossii v XX veke $s$ točki zrenija mirovych modernizacij. Moskva: ROSSPEN, 1998. 264 s. ISBN 5-86004-173-X

[13] KREJČÍ, O.: Mezinárodní politika. Praha: Ekopress, 2001. 709 s. ISBN 80-86119-45-9

[14] MAU, V. A.: Ekonomika i vlastj. Političeskaja istorija ekonomičeskoj reformy v Rossii, 1985-1994 gg. Moskva: „Delo Ltd“, 1995. 112 s. ISBN 5-86461-161-1

[15] NÁLEVKA, V.: Světová politika ve 20. století (II.). 2. vydání. Praha: Nakladatelství Aleš Skřivan ml., 2005. 284 s. ISBN 80-86493-16-4

[16] O'HEARN, D.: The Consumer Second Economy: Size and Effects, in: Soviet Studies, Vol. 32, 1980, No. 2, pp. 218-234. URL: http://links.jstor.org/sici?sici=0038-5859\% 28198004\%2932\%3A2\%3C218\%3ATCSESA\%3E2.0.CO\%3B2-L [19. 3. 2006] 
[17] PEREDERIJ, S. V.: "Perestrojka” v SSSR glazami sovetskich i amerikanskich avtorov. Opyt srovnitelnogo političeskogo issledovanija. Pjatigorsk: Izdatelstvo Pjatigorskogo gosudarstvennogo lingvističeskogo universiteta, 1997. 216 s. ISBN 5-8996-131-3

[18] PODBEREZKIN, A. I. i kol.: Rossija - 2000. Sovremennaja političeskaja istorija (1985-1999 gg.), T. 1, Chronika i analitika. Nauchnoe izdanie. Moskva: ZAO INF «RAU - Universitet», 2000. 1144 s. ISBN 5-86014-122-X

[19] POPOV, V. - SCHMELEV, N.: Sovetskaja ekonomika: ot plana k rynku. Moskva: Progress, 1991. 208 s. ISBN 5-01-003282-1

[20] RADCHENKO, V. V.: Ekonomičeskie zakony i perestrojka socialističeskogo chozjastvovanija, mežvuzovskij sbornik statej. Kujbyšev: Kujbyševskij gosudarstvennyj universitet, 1990. $135 \mathrm{~s}$. ISBN 5-230-05872-2

[21] SADRIEV, M. M. - SAFAROV, T. A.: Ideologija politiki socialno-ekonomičeskich reform $v$ Rossii. UFA 1997. $140 \mathrm{~s}$.

[22] SEIDL-HOHENVELDERN, I.: Mezinárodní právo veřejné. Praha: ASPI Publishing, 2001. 415 s. ISBN 80-85963-82-5

[23] STEPHAN, P. B. III: Perestroyka and Property: The Law of Ownership in the Post-Socialist Soviet Union, in: The American Journal of Comparative Law, Vol. 39, No. 1. (Winter, 1991), pp. 35-65. URL: http://links.jstor.org/sici?sici=0002-919X\% 28199124\%2939\%3A1\%3C35\%3APAPTLO\%3E2.0.CO\%3B2-T [23. 3. 2007]

[24] SUSLOV, JU. P.: Radikalnye peremeny v SSSR (1985-1991 gg.). Saratov: Izdatelstvo Saratovskogo universiteta, 2000. 40 s. ISBN 5-292-02447-5

[25] TARSCHYS, D.: The Success of a Failure: Gorbachev's Alcohol Policy, 1985-88, in: Europe-Asia Studies, Vol. 45, 1993, No. 1, pp. 7-25. URL: http://links.jstor.org/ sici?sici $=0966-8136 \% 281993 \% 2945 \% 3 \mathrm{~A} 1 \% 3 \mathrm{C} 7 \% 3 \mathrm{ATSOAFG} \% 3 \mathrm{E} 2.0 . \mathrm{CO} \% 3 \mathrm{~B} 2-7$ [19. 3. 2006]

[26] TIMOFEEV, T. T.: Perestrojka i sovremennyj mir. Moskva: Meždunarodnye otnǒ̌enija, 1989. 352 s. ISBN 5-7133-0163-X

[27] TREML, V. G.: Alcohol in the USSR: A Fiscal Dilemma, in: Soviet Studies, Vol. 27, No. 2. (Apr., 1975), pp. 161-177. URL: http://links.jstor.org/sici?sici=0038-5859\% 28197504\%2927\%3A2\%3C161\%3AAITUAF\%3E2.0.CO\%3B2-R [23. 3. 2007]

[28] ZHUKOV, V. I.: Rossijkie preobrazovanija: sociologija, ekonomika, politika. Moskva: Akademičeskij Projekt, 2003. 656 s. ISBN 5-8291-0206-4

[29] ŽALOUDEK, K.: Encyklopedie politiky. Praha: Nakladatelství Libri, 1999. 559 s. ISBN 80-85983-75-3 